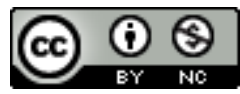

Jurnal Pendidikan Matematika Indonesia is licensed under A Creative Commons Attribution-Non Commercial 4.0 International License.

\title{
PROFIL PENALARAN SISWA SMP DALAM PEMECAHAN MASALAH MATEMATIKA TIMSS DITINJAU DARI PERBEDAAN GENDER
}

\author{
Sukriadi $^{1)}$, Kurniawan ${ }^{2)}$ \\ 1) Universitas Mulawarman, Samarinda, Indonesia \\ E-mail: sukriadi@fkip.unmul.ac.id \\ ${ }^{2)}$ Universitas Mulawarman, Samarinda, Indonesia
}

\begin{abstract}
Penelitian ini bertujuan untuk mendeskripsikan profil penalaran siswa SMP kelas VIII gender laki-laki dan perempuan dalam pemecahan masalah matematika TIMSS di SMPN 5 Samarinda.Penelitian ini merupakan jenis penelitian eksploratif dengan pendekatan kualitatif. Penggunaan pendekatan kualitatif didasarkan atas pertimbangan karena penelitian ini berlatar alami dan instrumen utama dalam penelitian ini adalah peneliti sendiri. Analisis dilakukan secara mendalam pada siswa gender laki-laki dan perempuan dalam memecahkan masalah matematika yang diberikan. Tahapan analisis data dalam penelitian ini meliputi tahap klasifikasi data, reduksi data, penyajian data, dan interpretasi data.Hasil penelitian menunjukkan bahwa subjek gender laki-laki mampu memahami masalah dengan baik informasi yang diketahui dan kecukupan informasi dari masalah matematika TIMSS, serta dapat melakukan penyelesaian dengan baik dan mengungkapkan bahwa langkah yang dilakukan telah sesuai dengan rencana. Sedangkan penalaran subjek gender perempuan yaitu subjek telah mampu memahami masalah dengan menyebutkan informasi yang diketahui, namun belum mampu menganalisis masalah dengan tepat, sehingga pada tahap melaksanakan pemecahan masalah subjek gender perempuan menunjukkan hasil yang belum baik.
\end{abstract}

Keywords: penalaran, pemecahan masalah matematika TIMSS, gender, siswa SMP

\section{Pendahuluan}

Matematika merupakan salah satu mata pelajaran yang diajarkan di semua jenjang pendidikan sekolah dan memiliki peran penting dalam penguasaan ilmu pengetahuan dan teknologi. Matematika merupakan ilmu pengetahuan yang mempunyai peranan penting dalam perkembangan ilmu pengetahuan dan teknologi. Seiring dengan peranan pentingnya, matematika juga mempunyai keterkaitan dengan ilmu pengetahuan lainnya. Matematika diberikan kepada siswa dimulai dari sekolah dasar hingga perguruan tinggi, sehingga matematika mempunyai banyak kemampuan untuk membekali siswa. Melalui pembelajaran matematika siswa mulai diajarkan untuk memiliki kemampuan berpikir logis, kritis, analisis, sistematis serta kemampuan bekerja sama dalam suatu kelompok.

Dalam kurikulum 2013 diungkapkan bahwa kompetensi lulusan dalam bidang studi matematika adalah mengusung adanya peningkatan dan keseimbangan soft skills dan hard skills yang meliputi aspek kompetensi sikap, pengetahuan, dan keterampilan dalam bidang matematika. Proses pembelajaran pada kurikulum 2013 setara dengan proses ilmiah, oleh karena itu kurikulum 2013 menggunakan pendekatan ilmiah atau pendekatan saintifik. Pendekatan saintifik berbasis pada konsep, teori dan fakta empiris yang dapat dipertanggungjawabkan. Menurut Permendikbud No. 81 A tahun 2013 dijelaskan bahwa proses pembelajaran berdasarkan pendekatan saintifik terdiri dari mengamati, menanya, mengumpulkan informasi, mengasosiasi (mengolah informasi) dan mengkomunikasikan

. Dan salah satu harapan yang ingin dicapai setelah siswa belajar seperti yang tertuang dalam kompetensi inti mata pelajaran Matematika kelas VIII yaitu: Mengolah, menyaji, dan menalar dalam ranah konkret (menggunakan, mengurai, merangkai, memodifikasi, dan membuat) dan ranah abstrak (menulis, membaca, menghitung, menggambar, dan mengarang) sesuai dengan yang dipelajari di sekolah dan sumber lain yang sama dalam sudut pandang/teori (Kemendikbud, 2013).

Berdasarkan tujuan diajarkannya Matematika dalam Kurikulum 2013, tujuan setelah siswa belajar Matematika adalah siswa menggunakan penalaran untuk melakukan manipulasi matematika dalam membuat generalisasi, menyusun bukti, menarik kesimpulan yang diterapkan dalam pemecahan masalah. Penalaran dan pembelajaran 
matematika saat erat kaitannya, seperti yang dinyatakan oleh NCTM (dalam Subarinah, 2013) yang menyebutkan ada lima standar proses pendidikan matematika, yaitu (1) pemecahan masalah, (2) penalaran, dan bukti, (3) komunikasi, (4) koneksi, dan (5) representasi. Stacey (2010) menyatakan "reasoning in mathematics is a cognitive process of looking for reasons and looking for conclusions", penalaran matematika adalah proses kognitif dalam mencari alasan dan mencari kesimpulan.

TIMSS (Trend in International Mathematics and Science Study) adalah studi internasional yang mengukur kemampuan siswa dibidang matematika dan sains. Dan dalam TIMSS 2011 assessment framework (Mullis, at al, 2009), terbagi atas dua dimensi, pertama dimensi konten meliputi empat domain yaitu Bilangan, Aljabar, Geometri, dan Data dan Peluang. Kedua dimensi kognitif meliputi pengetahuan (knowing), penerapan (appliying), dan penalaran (reasoning).

TIMSS menampilkan empat tingkat pada skala sebagai standar internasional yaitu standar mahir (625), standar tinggi (550), standar menengah (475), dan standar rendah (400). Capaian rata-rata peserta Indonesia pada TIMSS 2011 adalah 386 yang berarti berada pada level rendah. Berikut adalah tabel persentase hasil capaian peserta didik Indonesia dalam TIMSS 2011, untuk masing domain konten dan domain kognitif dibandingkan dengan negara lainnya.

TABEL I

PRESTASI MATEMATIKA DALAM DOMAIN KOGNITIF REASONING BERDASARKAN GENDER

\begin{tabular}{lcc}
\hline \multirow{2}{*}{ Negara } & \multicolumn{2}{c}{ Reasoning } \\
\cline { 2 - 3 } & Perempuan & Laki-laki \\
\hline Indonesia & $391(4.2)$ & $384(4.3)$ \\
Rata-rata & $466(0.7)$ & $463(0.8)$ \\
Internasional & & \\
\hline
\end{tabular}

Sumber: (Mullis, at all, 2012)

Pada tabel 1.terlihat bahwa tidak ada perbedaan yang signfikan untuk gender laki-laki dan perempuan pada domain kognitif reasoning (penalaran) baik Indonesia maupun untuk rata-rata internasional. Namun hal ini berbeda menurut Zhu (2007) yang menyatakan bahwa terdapat perbedaan pemecahan matematika dipengaruhi perbedaan gender, perbedaan pengalaman dan perbedaan pendidikan.

Krutetskii (dalam Nafi'an, 2011) menjelaskan perbedaan antara laki-laki dan perempuan dalam belajar matematika sebagai berikut: (1) Laki-laki lebih unggul dalam penalaran, perempuan lebih unggul dalam ketepatan, ketelitian, kecermatan, dan keseksamaan berpikir, (2) Lakilaki memiliki kemampuan matematika dan mekanika yang lebih baik daripada perempuan, perbedaan ini tidak nyata pada tingkat sekolah dasar tetapi menjadi tampak lebih jelas pada tingkat yang lebih tinggi.

Tujuan dari penelitian ini adalah: untuk mengetahui bagaimanakah profil penalaran siswa SMP gender laki-laki dan gender perempuan dalam pemecahan masalah matematika TIMSS.

\section{KAJIAN PUSTAKA}

Mansi (dalam Gunhan, 2014) mendefinisikan penalaran adalah kemampuan berpikir runtut dan logis dan menarik kesimpulan dari fakta yang diketahui atau diasumsikan. Dwirahayu (dalam Zulkardi, 2013) menyatakan bahwa penalaran adalah proses perambahan kesimpulan logis berdasarkan fakta dan sumber yang relevan, proses tranformasi yang diberikan dalam urutan tertentu untuk mencapai kesimpulan. Stylianides (dalam Bieda, 2013) menyatakan konseptualisasi penalaran dan pembuktian sebagai berbagai kegiatan yang terlibat dalam argumentasi matematika, termasuk generalisasi hubungan matematika dalam pola tertentu, menghasilkan dugaan, menghasilkan pembenaran atau bukti, dan mengevaluasi pembenaran yang diberikan atau bukti.

TIMSS adalah studi internasional yang mengukur kemampuan siswa dibidang matematika dan sains. TIMSS bertujuan untuk mengukur prestasi matematika dan ilmu pengetahuan alam siswa kelas IV serta kelas VIII di negara-negara peserta. Bagi Indonesia, manfaat yang dapat diperoleh antara lain untuk mengetahui posisi prestasi siswa Indonesia bila dibandingkan dengan prestasi siswa di negara lain dan faktor-faktor yang mempengaruhinya. Oleh karena itu, hasil studi ini diharapkan dapat digunakan sebagai masukan dalam perumusan kebijakan untuk peningkatan mutu pendidikan.

Krulik Kantowski (dalam Pehkonen, 2011) menyatakan bahwa suatu tugas dikatakan sebagai masalah jika solusinya mensyaratkan seorang individu untuk menggabungkan pengetahuan yang telah diperoleh sebelumnya dengan cara yang baru (bagi individu tersebut). Apabila individu tersebut dapat segera mengenali langkah-langkah yang diperlukan untuk menyelesaikan tugas tersebut, maka tugas tersebut bukanlah suatu masalah melainkan hanya merupakan tugas rutin/standar.

Krulik dan Rudnick (dalam Carson, 2007) masalah adalah suatu situasi yang dihadapi oleh seseorang atau kelompok yang memerlukan suatu pemecahan tetapi individu atau kelompok tersebut tidak memiliki cara yang langsung untuk menemukan solusinya. Reed (2011) menyatakan bahwa pemecahan masalah merupakan sebuah upaya untuk mengatasi rintangan yang menghambat jalan menuju solusi. Hal ini sependapat dengan Santrock (2009) yang menyatakan bahwa pemecahan masalah melibatkan penemuan sebuah cara yang sesuai untuk mencapai suatu tujuan.

NCSM (Pehkonen, 2011: 1) lebih lanjut menyatakan bahwa "problem solving can be understood as a process where previously acquired data are used in a new and unknown situation". Pemecahan masalah dapat diartikan sebagai suatu proses dimana data/informasi yang telah diperoleh sebelumnya digunakan untuk menyelesaikan suatu situasi yang baru yang belum diketahui solusinya.

Untuk memecahkan suatu masalah, diperlukan suatu pendekatan tertentu. Polya (1973) mengajukan empat fase pemecahan masalah, yaitu:

1. Memahami masalah (understanding the problem) 


\section{- - - Jurnal Pendidikan Matematika Indonesia \\ Volum 4 Nomor 1 bulan Maret 2019 Page 36 - 41 \\ p-ISSN: 2477-5967 e-ISSN: 2477-8443}

2. Menyusun rencana (devising a plan)

3. Melaksanakan rencana (carrying out the plan)

4. Memeriksa kembali (looking back)

Pemecahan masalah matematika yang dimaksud dalam penelitian ini adalah usaha untuk memperoleh suatu solusi dari permasalahan matematika, dengan menggunakan empat fase/langkah yaitu memahami masalah, menyusun rencana, melaksanakan rencana, memeriksa kembali.

Istilah "gender" dikemukakan oleh para ilmuwan sosial dengan maksud untuk menjelaskan perbedaan laki-laki dan perempuan yang mempunyai sifat bawaan (ciptaan Tuhan) dan bentukan budaya (konstruksi sosial). Seringkali terjadi pencampuradukkan ciri-ciri manusia yang bersifat kodrati (tidak berubah) dan yang bersifat non-kodrati yang bisa berubah dan diubah.

Perbedaan Gender yang dimaksud dalam penelitian ini adalah perbedaan jenis kelamin antara laki-laki dan perempuan serta perilaku yang sesuai dengan perannya masing-masing dalam kehidupan sosial

Pada penelitian ini, profil penalaran siswa dalam pemecahan masalah matematika TIMSS adalah sebuah gambaran atau deskripsi tentang proses menarik kesimpulan berdasarkan fakta-fakta yang diberikan dalam menyelesaikan masalah matematika TIMSSyang diberikan, sesuai dengan keadaan yang sebenarnya (apa adanya) berdasarkan tahapan-tahapan pemecahan masalah matematika yang dikemukakan Polya. Indikator penalaran yang digunakan dalam penelitian ini bersumber dari English yang mencakup beberapa proses, antara lain: mengumpulkan bukti, menganalisis data, membuat dugaan, membangun argumen, menarik simpulan, mensahihkan simpulan yang logis, serta membuktikan kebenaran pernyataan dengan tegas.

\section{MEtode PENELITIAN}

Penelitian ini merupakan jenis penelitian eksploratif dengan pendekatan kualitatif. Penggunaan pendekatan kualitatif didasarkan atas pertimbangan karena penelitian ini berlatar alami dan instrumen utama dalam penelitian ini adalah peneliti sendiri. Analisis dilakukan secara mendalam pada siswa gender laki-laki dan perempuan dalam memecahkan masalah matematika yang diberikan.

Subjek dalam penelitian ini adalah 2 siswa kelas VIII SMP yang masing-masing dengan gender laki-laki dan perempuan.

Instrumen yang digunakan untuk mengumpulkan data pada penelitian ini adalah:

1. Instrumen Utama

Pada penelitian ini, yang menjadi instrumen utama adalah peneliti sendiri.

2. Instrumen Pendukung

a. Tes Kemampuan Matematika (TKM)

Instrumen yang digunakan dalam penentuan subjek penelitian adalah tes kemampuan matematika. Soal tes kemampuan matematika yang digunakan dalam penelitian ini adalah soal Ujian Nasioanal SMP/MTs yang dimodifikasi menjadi soal uraian sebanyak 10 butir soal.Sebelum instrumen TKM diberikan kepada calon subjek penelititan, terlebih dahulu draft TKM divalidasi ahli.

b. Tugas Pemecahan Masalah TIMSS (TPMT)

Tugas pemecahan masalah matematika TIMSS ini diadopsi dari soal TIMSS 2011 domain kognitif penalaran untuk melihat penalaran siswa kelas VIII SMP/MTs. Sebelum TPMT diberikan kepada subjek, soal tersebut divalidasi terlebih dahulu.

c. Pedoman Wawancara (PW)

Pedoman wawancara berfungsi sebagai acuan atau pedoman bagi peneliti sehingga wawancara menjadi terarah.

Teknik pengumpulan data pada penelitian ini adalah dengan memberikan TKM kepada siswa kelas VIII. Hasil TKM dirangking dan dipilih masing-masing satu siswa gender laki-laki dan satu siswa gender perempuan berdasarkan nilai TKM yang relatif sama dan relatif tinggi. Setelah terpilih, kedua responden diberikan TPMT dan wawancara. Setelah subjek penelitian menyelesaikan TPMT maka peneliti melakukan wawancara terhadap subjek secara mendalam guna memverifikasi data hasil tes tertulis. Selain itu, wawancara juga digunakan untuk memperoleh informasi baru yang mungkin tidak diperoleh saat tugas tertulis, karena tidak semua yang dipikirkan siswa mampu dituliskan, hal ini mungkin dapat terungkap ketika wawancara. Untuk mengetahui keabsahan data yang diperoleh, maka perlu dilakukan uji kreadibilitas data. Dalam penelitian ini, peneliti menggunakan triangulasi waktu, karena waktu seringkali mempengaruhi kredibilitas data.

Data dikatakan valid jika terdapat konsistensi atau banyak kesamaan pandangan antara data pertama dan data kedua. Kesamaan pandangan yang dimaksud adalah kesamaan makna antara hasil tertulis atau penyataan lisan atau aktivitas yang dilakukan pada TPMT 1 dengan hasil tertulis atau penyataan lisan atau aktivitas yang dilakukan pada TPMT 2. Soal TPMT 2 merupakan soal yang sejenis dengan TPMT 1 dan hanya berbeda simbol variabelnya saja. Jika data belum valid maka dilakukan pengumpulan data kembali di waktu yang berbeda dengan sebelumnya sampai diperoleh data yang valid. Selanjutnya data yang valid digunakan dalam penelitian ini

\section{IV.HASIL DAN PEMBAHASAN}

Pada penelitian ini diberikan masing-masing responden diberikan 2 soal TPMT sebagai berikut:

1

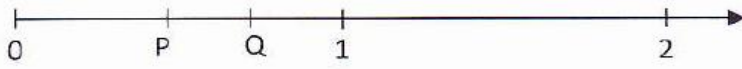

$\mathrm{P}$ dan $\mathrm{Q}$ menyatakan dua bilangan pecahan pada garis bilangan di atas. Jika $P \times Q=N$, tentukan letak $N$ pada garis bilangan!

Gambar 1. Soal Pertama TPMT 


\section{- - - - Jurnal Pendidikan Matematika Indonesia \\ Volum 4 Nomor 1 bulan Maret 2019 Page 36 - 41 \\ p-ISSN: 2477-5967 e-ISSN: 2477-8443}

2. Andy memiliki tiga buah kotak dengan berat setiap kotak adalah sama. Ketika Dia menimbang satu kotak dengan beban timbangan seberat 8 gram, ini yang terjadi.

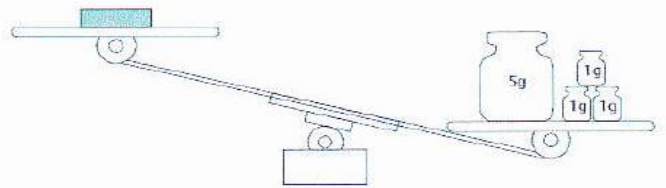

Ketika Dia menimbang semua kotak dengan beban timbangan seberat 20 gram, ini yang terjadi.

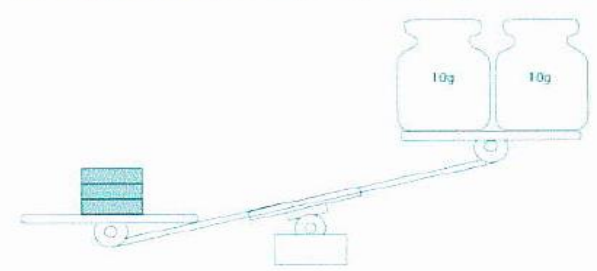

Tentukan berat satu kotak!

Gambar 2. Soal Kedua TPMT

Pada soal pertama, penalaran subjek gender laki-laki dalam memahami masalah yaitu menyebutkan yang diketahui adalah $p$ dan $q$ pada garis bilangan dan $n$ merupakan hasil kali $p$ dan $q$, dan mengungkapkan yang ditanyakan adalah menentukan letak $n$ pada garis bilangan. Serta subjek juga menganalisis data yang diperoleh dengan mengungkapkan bahwa informasi pada masalah telah cukup untuk memecahkan masalah dengan alasan hasil membaca soal. Penalaran subjekdalam menyusun rencana, menentukan nilai $p$ dan $q$. Kemudian menentukan hasil kali $p$ dan $q$ dan akan diketahui letak $n$.

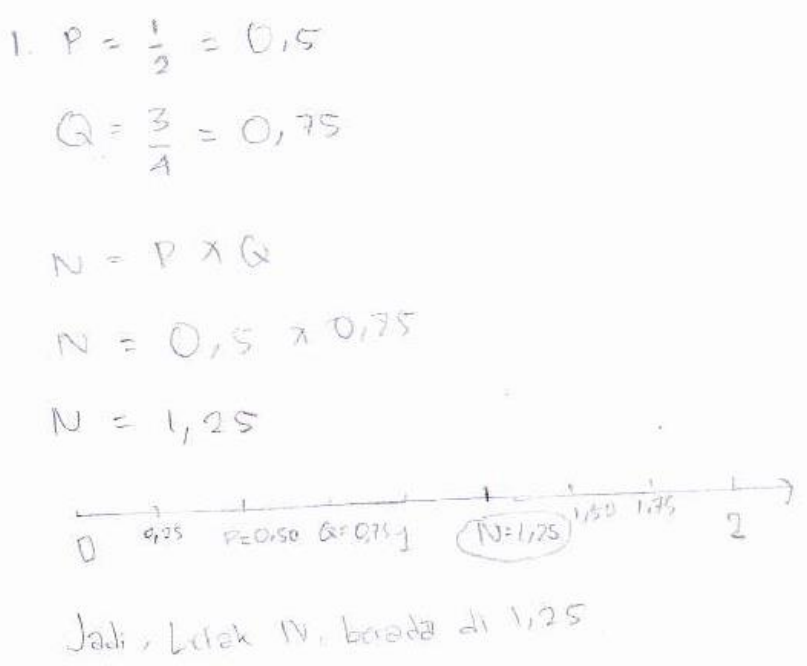

Gambar 3. Jawaban Soal Kedua TPMT Subjek Gender Laki-laki

Pada tahap melaksanakan, subjek gender laki-laki memisakan $p$ dan $q$ dengan suatu bilangan yaitu $\frac{1}{2}$ dan $\frac{3}{4}$ dengan alasan bahwa $p$ terletak ditengah antara 0 dan 1 dan $q$ terletak diantara $p$ dan 1 . Kemudian Subjek menghitung perkalian $p$ dan $q$ berdasarkan informasi yang diketahui pada masalah yaitu $p \times q=n$, hasil dari perkalian tersebut menjadi dasar Subjek menentukan letak $n$. Subjek mengungkapkan bahwa langkah yang dilakukan telah sesuai dengan rencana yaitu menentukan/memisalkan terlebih dahulu nilai $p$ dan $q$ kemudian menentukan nilai $n$, sehingga akan diketahui letak $n$ pada garis bilangan. Selanjutnya tahap memeriksa kembali, Subjek memeriksa hasil perkalian $p \times q=n=1,25$ dan juga memeriksa letak $n$ berada di tengah-tengah antara 1 dan 1,50.

Pada soal kedua, penalaran subjek dalam memahami masalah, Subjek mengungkapkan yang diketahui adalah terdapat 3 buah balok logam yang berat setiap balok logam sama. Anak timbangan seberat 8 gram dapat mengangkat 1 buah balok logam, 3 buah balok logam dapat mengangkat anak timbangan seberat 20 gram, dan yang ditanyakan adalah berat 1 buah balok logam. Dan juga Subjek menjelaskan bahwa belum mengetahui dengan jelas kecukupan informasi untuk sementara informasi telah cukup karena diketahui 8 gram dapat mengangkat 1 buah logam dan 3 buah logam dapat mengangkat 20 gram. Penalaran Subjekdalam menyusun rencana, Subjek menjelaskan akan mencari berat 1 buah balok logam yang kurang dari 8 gram dan jika 3 buah balok logam maka beratnya lebih dari 20 gram.

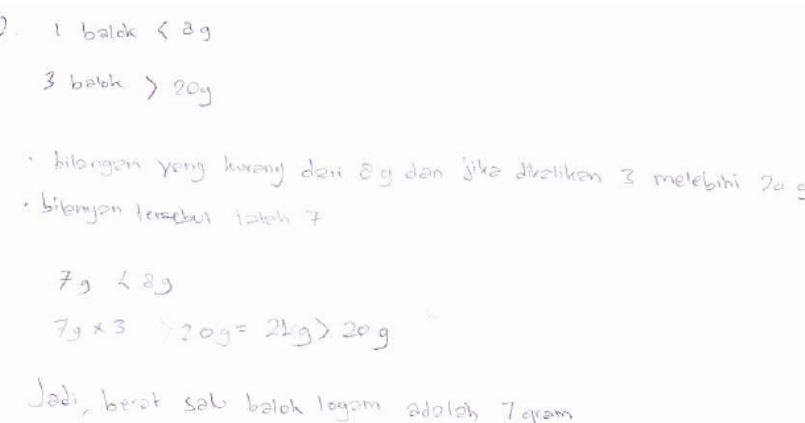

Gambar 4. Jawaban Soal Kedua TPMT Subjek Gender Laki-laki

Pada tahap melaksanakan, menyajikan permasalahan dalam bentuk simbol, bahwa 1 balok logam dapat diangkat oleh 8 gram yang disajikan dengan simbol kurang dari dan 3 buah balok logam dapat mengangkat 20 gram dengan simbol lebih dari. Kemudian mengambil hipotesis berat 1 balok logam yaitu 7 gram dengan alasan bahwa 7 kurang dari 8 gram dan jika dikalikan 3 hasilnya sama dengan 21 gram, dan itu lebih dari 20 gram dan bisa mengangkat 20 gram. Dan Subjek memilih berat 1 buah balok logam misalnya 6 gram, walaupun 6 gram kurang dari 8 tetapi jika dikalikan 3 hasilnya kurang dari 20 gram dan tidak bisa mengangkat oleh 20 gram.

Selanjutnya tahap memeriksa kembali, Subjek memeriksa apakah ada berat 1 buah balok logam selain 7 gram yang termasuk, dan Subjek menyatakan tidak adaberat 1 buah balok logam selain 7, yang kurang dari 8 gram dan jika dikalikan 3 hasilnya bisa mengangkat atau lebih dari 20 gram. Selain itu Subjek memeriksa apakah ada informasi yang belum Subjek baca.

Pada Soal pertama, Penalaran subjek perempuan dalam memahami masalah yaitu subjek menyebutkan yang diketahui $p$ dan $q$ menyatakan dua bilangan pecahan, pada garis bilangan, dan $p \times q=n$. Yang ditanya adalah menentukan letak $n$ pada garis bilangan. Serta subjek juga menganalisis data yang diperoleh dengan mengungkapkan bahwa informasi pada masalah telah cukup karena $p$ dan $q$ sudah jelas pada garis bilangan, tinggal menentukan nilai $p$ 
dan $q$. Penalaran subjek dalam menyusun rencana, mengambar garis bilangan, menentukan nilai $p$ dan $q$, menghitung panjang $p$ dan $q$, kemudian menentukan letak $n$.

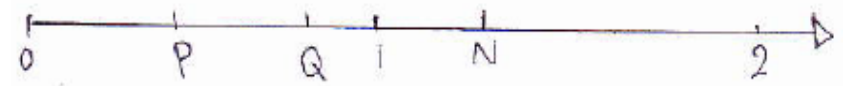

\section{$P \times Q=N$}

Gambar 5. Jawaban Soal Pertama TPMT Subjek Gender Perempuan

Pada tahap melaksanakan, Subjek menentukan letak titik $n$ dengan cara menghitung jarak $p$ dan $q$ setelah mendapatkan jarak $p$ dan $q$ kemudian menentukan letak $n$ dengan cara menjumlahkan sejarak $p$ dan $q$ dengan titik awal di $q$. Selanjutnya tahap memeriksa kembali, Subjek memeriksa PR memeriksa hasil perhitungan jarak antara $p$ dan $q$.

Pada soal kedua, penalaran subjek gender perempuan dalam memahami masalah, Subjek mengungkapkan jika Jo menimbang satu balok logam berat dengan beban timbangan 8 gram, satu balok logam lebih ringan daripada beban timbangan. Dan jika semua balok logam dengan berat ditimbangan dengan beban timbangan seberat 20 gram, tiga balok logam lebih berat daripada 20 gram. Dan yang ditanyakan adalah berapa berat 1 buah balok logam. Serta menggungkapakan bahwa informasi sudah cukup karena pada soal sudah cukup jelas apa yang diketahui.

$$
\begin{aligned}
& \text { Jawab: } \\
& \text { DIK = I kotak beban 8g. Lebih ringan } \\
& 3 \text { kotak (semuanya) beban } 209 \text { = lebih berat } \\
& \text { DIT. Berat I kotak =? } \\
& \text { Di jawab }=1 \text { kotak }=\text { ? } \\
& \begin{array}{l}
.2,5 \mathrm{~g} \\
\text { Jadi, berat, I kotak }=2,59
\end{array}
\end{aligned}
$$

Gambar 6. Jawaban Soal Kedua TPMT Subjek Gender Perempuan

Penalaran Subjek dalam menyusun rencana, Subjek menjelaskan akan mencari berat 1 buah balok logam dengan cara beban timbangan 20 gram dibagi dengan 8 gram. Pada tahap melaksanakan, menuliskan informasi pada masalah dengan bahasa sendiri terlihat dari PR menuliskan satu balok logam sama dengan 8 gram, semua balok logam sama dengan 20 gram. Kemudian PR menentukan berat 1 balok logam dengan cara 20 dibagi 8 gram dan diperoleh 2,5 gram. Selanjutnya tahap memeriksa kembali, Subjek memeriksa kembali informasi yang diperoleh pada soal apakah ada yang apakah ada yang salah menuliskan informasi. Dan memeriksa hasil yang diperoleh dari 20 gram dibagi 8 gram sama dengan 2,5 gram.

\section{SIMPULAN}

\section{Kesimpulan}

Dari hasil penelitian dapat disimpulkan bahwa subjek gender laki-laki mampu memahami dengan baik informasi yang diketahui dan kecukupan informasi dari masalah matematika TIMSS, serta dapat melakukan penyelesaian dengan baik dan mengungkapkan bahwa langkah yang dilakukan telah sesuai dengan rencana, sedangkan penalaran subjek gender perempuan yaitu subjek telah mampu memahami masalah sehingga dapat menyebutkan informasi yang diketahui namun belum mampu menganalisis dengan baik sehingga dalam tahap memeriksa belum bisa mendeteksi kekurangan atau kekeliruan dalam penyelesaian matematika TIMSS.

\section{Saran}

Berdasarkan uraian hasil penelitian, maka dapat disarankan bahwa:

1. Perlu merancang pembelajaran yang dapat meningkatkan penalaran siswa dengan memberikan contoh permasalahan matematika untuk domain penalaran.

2. Penelitian lebih mendalam untuk merancang dan mengembangkan perangkat pembelajaran dalam rangka meningkatkan kemampuan penalaran siswa.

\section{DAFTAR PUSTAKA}

Bieda, K. N. Et.al. (2013). Reasoning And Proving Opportunities In Elementary Mathematics Textbooks. Michigan State University, United States. International Journal of Educational Research. Elsevier.

Carson, J. (2007). A Problem With Problem Solving: Teaching Thinking Without Teaching Knowledge. The Mathematics Educator. 2007 Vol. 17 No 2, pp 714.

English, L.D. (2004). Mathematical And Analogical Reasoning of Young Learners. London: Lawrence Erlbaum Associates Publishers.

Gunhan, B. C. (2014). A Case Study On The Investigation Of Reasoning Skills In Geometry. Department of Primary Mathematics Education, Dokuz Eylul University.SouthAfrican Journal of Education; 34(2). Art. \# 910, 19 pages.

Kemendikbud. (2013). Permendikbud No 68 tentang Kerangka Dasar dan Struktur Kurikulum Sekolah Menengah Pertama/Madrasah Tsanawiyah. Jakarta: Kementrian Pendidikan dan Budaya.

Mullis, I.V.S., MartinM.O.,Ruddock, G.J., O’Sullivan, C.Y., Preuschoff, C. (2009). TIMSS 2011 Assessment Framework. Chestnut Hill : Boston College.

Mullis, I.V.S., Martin M.O., Foy, P., \& Arora, A. (2012). TIMSS 2011 Internastional Result in Mathematics. Chestnut Hill, MA: TIMSS \& PIRLS International Study Center. Boston College.

Nafi'an, I. (2011). Kemampuan Siswa Dalam Menyelesaikan Soal Cerita Ditinjau Dari Gender di Sekolahan Dasar. Makalah PROSIDING Seminar Nasional Matematika dan Pendidikan Matematika. FMIPA UNY ISBN:978-979-16353-6-3. 
Pehkonen, E. (2011). "Problem Solving in Mathematics Education in Finland". Different conceptions of the mathematical knowledge needed for teaching and how it can be acquired, and its relation to pedagogical knowledge. pp 1-5.

Polya, G. (1973). How To Solve It. New Jersey: Princeton University Press.

Reed, S. K. (2011). Kognisi: Teori dan Aplikasi. Jakarta: Salemba Humanika.

Santrock, J. W. (2009). Psikologi Pendidikan. Jakarta: Salemba Humanika.

Stacey, K.. (2010). Mathematics Teaching And Learning To Reach Beyond The Basics. Research Conference: University of Melbourne.

Subarinah, S. (2013). Profil Berpikir Kreatif Siswa Dalam Memecahkan Masalah Tipe Investigasi Matematik
Ditinjau Dari Perbedaan Gender. Makalah PROSIDING Seminar Nasional Matematika dan Pendidikan Matematika.FMIPA UNY ISBN : 978 $979-16353-9-4$.

Zhu, Z. (2007). Gender Differences in Mathematical Problem Solving Pattern: A review of literature. International Education Journal, Vol 8 No 2, 187203. ISSN 1443-1475, Shannon Research Press.

Zulkardi. (2013). Develop Inductive Reasoning On Pattern Numbers With A Realistic Mathematics Education Approach In The Ninth Grade Students In Mts AlKenaniyah, Jakarta. Proceeding The First South East Asia Design/Development Research (SEADR) International Conference, Sriwijaya University, Palembang. ISBN: 978-602-17465-1-6. 